\title{
Fundamentals of soil stabilization
}

\author{
Ali Akbar Firoozi ${ }^{1 *}$ (D, C. Guney Olgun², Ali Asghar Firoozi ${ }^{1}$ and Mojtaba Shojaei Baghini ${ }^{1}$
}

\author{
${ }^{*}$ Correspondence: \\ afiroozi@siswa.ukm.edu.my \\ 1 Department of Civil \& \\ Structural Engineering, \\ Universiti Kebangsaan \\ Malaysia (UKM), Bangi, \\ Selangor, Malaysia \\ Full list of author information \\ is available at the end of the \\ article
}

\begin{abstract}
Clayey soils are usually stiff when they are dry and give up their stiffness as they become saturated. Soft clays are associated with low compressive strength and excessive settlement. This reduction in strength due to moisture leads to severe damages to buildings and foundations. The soil behavior can be a challenge to the designer build infrastructure plans to on clay deposits. The damage due to the expansive soils every year is expected to be $\$ 1$ billion in the USA, $£ 150$ million in the UK, and many billions of pounds worldwide. The damages associated with expansive soils are not because of the lack of inadequate engineering solutions but to the failure to identify the existence and magnitude of expansion of these soils in the early stage of project planning. One of the methods for soil improvement is that the problematic soil is replaced by suitable soil. The high cost involved in this method has led researchers to identify alternative methods, and soil stabilization with different additives is one of those methods. Recently, modern scientific techniques of soil stabilization are on offer for this purpose. Stabilized soil is a composite material that is obtained from the combination and optimization of properties of constituent materials. Adding cementing agents such as lime, cement and industrial byproducts like fly ash and slag, with soil results in improved geotechnical properties. However, during the past few decades, a number of cases have been reported where sulfate-rich soils stabilized by cement or lime underwent a significant amount of heave leading to pavement failure. This research paper addressed the some fundamental and success soil improvement that used in civil engineering field.
\end{abstract}

Keywords: Soil improvement, Cement, Lime, Fly ash, Fibers, Advantages and disadvantages, Sulfate attack

\section{Introduction}

Soils can be stabilized by the addition of cement or lime. Such stabilization processes improve the various engineering properties of the stabilized soil and generate an improved construction material. Increase in soil strength, durability stiffness, and reduction in soil plasticity and swelling/shrinkage potential are the benefit of soil stabilization [1-5]. The concept of stabilization is 5000 years old. McDowell [6] indicated that stabilized earth roads were used in ancient Egypt and Mesopotamia and that the Greeks and Romans used lime as a stabilizer. However, recent heaving and premature pavement failures in lime and cement-treated subgrades containing sulfates led to questioning the validity of calcium-based stabilization. When expansive soils containing sulfates are treated with calcium-based stabilizers, the calcium from the stabilizer reacts with soil sulfates and alumina to form the expansive mineral ettringite [7-9]. The first soil

(c) The Author(s) 2017. This article is distributed under the terms of the Creative Commons Attribution 4.0 International License (http://creativecommons.org/licenses/by/4.0/), which permits unrestricted use, distribution, and reproduction in any medium, provided you give appropriate credit to the original author(s) and the source, provide a link to the Creative Commons license, and indicate if changes were made. 
stabilization tests were performed in the United States in 1904 [10]. Cement was introduced as a stabilizer to construct a street in Sarasota, FL, in 1915 (ACI 1997), and lime was first involved in short stretches of highway with the expansion of roads to cater for the growth of vehicle traffic in 1924 [11, 12]. Traditional stabilizers typically depend on pozzolanic reactions and cation exchange to modify and stabilize soil [13, 14]. Pozzolanic reactions occur when siliceous and aluminous materials react chemically with calcium hydroxide at regular temperatures to form cementitious compounds. On the other hand, a cation exchange occurs when the soil is able to exchange free cations available in the exchange locations [15-18]. The main objectives of this research study is addressed to different types of stabilization and comparing the advantage and disadvantage of each method of stabilization.

\section{Soil stabilization}

Generally, soil stabilization is a method of improving soil properties by blending and mixing other materials. Improvements include increasing the dry unit weight, bearing capabilities, volume changes, the performance of in situ subsoils, sands, and other waste materials in order to strengthen road surfaces and other geotechnical applications.

\section{Stabilization using cement}

One of the common methods of chemical stabilization is to mix soil with cement to form a product named as soil-cement [19]. Soil-cement can be defined as a mixture of soil and measured amounts of Portland cement and water and compacted to the desired density. Soil-cement has been used as a base material as an adoption of improved measure in many projects, such as slope protection of dams and embankments, pavement of highways, building pads, terminals for rail and truck, composting facilities, cheap base for streets, parking lots, channels and reservoir linings, mass soil-cement placement for dikes, foundation stabilization etc. The soil-cement technique has been practiced almost for 100 years. It serves to amend the mechanical and the engineering properties of the soil. The new performance depends on the ability of the additives to react with the mixing soil. There are four main properties of soil; strength, permeability, volume stability, and durability that can be enhanced with additives $[20,21]$. The choice of a specific additive depends on the type of soil, service that is required to serve and the surrounding environment. When water is mixed with cement, hydration occurs, meaning cementing compounds of calcium-silicate-hydrate $(\mathrm{C}-\mathrm{S}-\mathrm{H})$ and calcium-aluminate-hydrate $(\mathrm{C}-\mathrm{A}-\mathrm{H})$ are formed and excess calcium hydroxide $(\mathrm{CaOH})$ is released, approximately $31 \%$ by weight [22]. Formation of $\mathrm{C}-\mathrm{S}-\mathrm{H}$ and $\mathrm{C}-\mathrm{A}-\mathrm{H}$ occurs when crystals begin forming a few hours after the water and cement are mixed; crystals will continue to form as long as unreacted cement particles and free water remain within the mixture [15]. Five standard types of Portland cement (Types I through V) are available as specified by ASTM C150. The process of cementation and the results of soil-cement and lime stabilization are similar, they used in quantities too small to provide high-strength cementing action. They reduce the plasticity of clay soils. Calcium chloride or sodium chloride are added to the soil to retain moisture and also control dust, to hold fine material for better compaction, and to reduce frost heave by lowering the freezing point of water in the soil. Kezdi [23] reports that cement treatment slightly increases the maximum dry density 
of sand and highly plastic clays but it decreases the maximum dry density of silt [24]. In contrast studies by Deng and Tabatabai [24] shows that cement increases the optimum water content but decreases the maximum dry density of sandy soils [25]. Cement increases plastic limit and reduces liquid limit, which mainly reduces plasticity index [24]. The other significant effects of soil-cement stabilization is reduction in shrinkage and swell potential, increase in strength, elastic modulus, and resistance against the effect of moisture, freeze, and thaw. Cement treated soils show a brittle behavior compare of non-treated soils $[26,27]$. Cement can be applied to stabilize any type of soil, except soils with organic content greater than $2 \%$ or having $\mathrm{pH}$ lower than 5.3 (ACI 230.1R-90, 1990). The use of cement in granular soils has proven to be economical and effective because smaller amounts of cement are required. In addition, soils that have a PI value higher than 30 are difficult to mix with cement. To avoid this issue, lime can be added prior to mixing in cement; this initial step will keep soils more workable [28-31].

Khemissa and Mahamedi [32] found that swell pressure decrease as the stabilizer content increased in cement treated samples. Cementitious links develop between the calcium silicate and calcium aluminate found in Portland cement with the soil particles [13, 14, 19]. Unlike lime, hydration in cement occurs at a faster pace which allows for an immediate strength gain. Therefore, there is no need of a mellowing period when stabilizing with cement; compaction of soil-cement samples is typically conducted within $2 \mathrm{~h}$ of initial mixing. The strength gain achieved during compaction may be below the ultimate strength of a soil-cement sample [13]. However, the cement stabilized soil will continue to gain strength over the course of several days [17, 33].

There are many factors contributing to the length of curing time required for strength gain in soil-cement samples. These include ambient air temperature, relative humidity, type of cement used, and concentration of cement used. Guthrie and Reese [34] found that the relative strength is sensitive to the previously mentioned factors, while the relative compaction is not. Faster wind speed, higher air temperature, lower relative humidity and longer delay in compaction commonly result in a poor strength.

\section{Stabilization using lime}

Limestone is broken down at elevated temperatures to form lime [17]. As a result, three forms of lime are produced: quicklime (calcium oxide- $\mathrm{CaO}$ ), hydrated lime (calcium hydroxide- $\mathrm{Ca}[\mathrm{OH}]_{2}$ ), and hydrated lime slurry; all of which can be used to treat soils. Quicklime is manufactured by chemically transforming calcium carbonate (limestone$\mathrm{CaCO}_{3}$ ) into calcium oxide. Furthermore, hydrated lime is created when quicklime chemically reacts with water. When hydrated lime is mixed with clay particles, it permanently forms strong cementitious bonds [35-37]. Lime has been known to reduce the swelling potential, liquid limit, plasticity index and maximum dry density of the soil, and increases its optimum water content, shrinkage limit and strength [19,38]. It improves the workability and compact ability of subgrade soils [39].

If quicklime is used, it immediately hydrates (i.e., chemically combines with water) and releases heat. Soils are dried, because water present in the soil participates in this reaction, and because the heat generated can evaporate additional moisture. The hydrated lime produced by these initial reactions will subsequently react with clay particles. These subsequent reactions will slowly produce additional drying because they reduce the soil's 
moisture holding capacity. If hydrated lime or hydrated lime slurry is used instead of quicklime, drying occurs only through the chemical changes in the soil that reduce its capacity to hold water and increase its stability. After initial mixing, the calcium ions $\left(\mathrm{Ca}^{2+}\right)$ from hydrated lime migrate to the surface of the clay particles and displace water and other ions. The soil becomes friable and granular, making it easier to work and compact. At this stage the Plasticity Index of the soil decreases dramatically, as does its tendency to swell and shrink. The process, which is called "flocculation and agglomeration," generally occurs in a matter of hours.

When adequate quantities of lime and water are added, the $\mathrm{pH}$ of the soil quickly increases to above 10.5, which enables the clay particles to break down. Silica and alumina are released and react with calcium from the lime to form calcium-silicate-hydrates $(\mathrm{CSH})$ and calcium-aluminate-hydrates $(\mathrm{CAH})$. CSA and $\mathrm{CAH}$ are cementitious products similar to those formed in Portland cement. They form the matrix that contributes to the strength of lime-stabilized soil layers. As this matrix forms, the soil is transformed from a sandy, granular material to a hard, relatively impermeable layer with significant load bearing capacity. The matrix formed is permanent, durable, and significantly impermeable, producing a structural layer that is both strong and flexible. However, alteration of particle structure occurs slowly, depending upon the type of clay present, a mellowing period from 1 to 4 days is allowed to obtain a homogeneous, friable mixture. These reactions maybe summarized as:

$$
\begin{aligned}
& \mathrm{Ca}^{2+}+\mathrm{OH}^{-}+\text {Soluble Clay Silica } \rightarrow \text { Calcium Silicate Hydrate }(\mathrm{CSH}) \\
& \mathrm{Ca}^{2+}+\mathrm{OH}^{-}+\text {Soluble Clay Alumina } \rightarrow \text { Calcium Alumina Hydrate }(\mathrm{CAH})
\end{aligned}
$$

Lime stabilization enhances engineering properties of soils, such as improved strength, higher resistance to fracture, fatigue, and permanent deformation, enhanced resilient properties, reduction in swelling; and resistance to the harmful effects of moisture. The most considerable improvements in these properties are observed in moderately to highly plastic clays [40, 41].

Al-Kiki et al. [42] acknowledged that over the time, the properties of treated soil affect the strength gain. Soil $\mathrm{pH}$, organic content, the quantity of exchangeable sodium, clay mineralogy, natural drainage, weathering conditions, extractable iron, carbonates and silica-alumina ratio are some of the properties which influence the gain in strength. The stabilization of acidic soil using lime, resulted in lower compressive strength than that of alkaline soil. Broderick and Daniel [43] reported that the lime and cement stabilized soils are less vulnerable to attack by organic chemicals in comparison to untreated soils [44]. Haraguchi et al. [44] investigated the variation of the engineering properties of freshly cement-stabilized decomposed granite soil cured in water and in $0.2 \mathrm{~N}$ acid solution, and indicated that the CBR obtained from the specimens cured in the $0.2 \mathrm{~N}$ acid solution was lower than that cured in water [45]. The strong alkaline conditions were able to release silica and alumina from the clay mineral and eventually react with lime to form new cementation products. The success of the lime treatment process is highly dependent on the available lime content, curing time, soil type, soil pH and clay minerals [46]. Limited research has been conducted to determine whether $\mathrm{pH}$ variations will affect properties of lime-stabilized soils. Additional studies are therefore necessary to explain 
the erosion mechanism of lime-stabilized soils due to $\mathrm{pH}$ variations [47-49]. However, experience shows that lime will react with many medium-, moderately fine- and finegrained soils to produce decreased plasticity, increased workability, reduced swell, and increased strength. Soils classified according to the USCS as $\mathrm{CH}, \mathrm{CL}, \mathrm{MH}, \mathrm{ML}, \mathrm{OH}$, OL, SC, SM, GC, GM, SW-SC, SP-SC, SM-SC, GWGC, GP-GC, ML-CL, and GM-GC should be considered as potentially capable of being stabilized with lime. Lime should be considered with all soils having a PI greater than 10 and more than 25 percent of the soil passing the No. 200 sieve [FM 5-472/NAVFAC MO 330/AFJMAN 32-1221(I)].

\section{Stabilization using fly ash}

Fly ash is one of four coal combustion products (CCPs) that are produced as a by-product of burning coal, two major groups, Class $\mathrm{C}$ and Class $\mathrm{F}$ fly ash are produced. Burning lignite and subbituminous coal produces Class $\mathrm{C}$ fly ash. However, burning anthracite, other known as bituminous coal, produces Class F fly ash [50]. Although there can be multiple variations of the chemical additive, fly ash particles generally consist of hollow spheres of silicon, aluminum, and iron oxides and unoxidized carbon all of which make both classes of fly ash pozzolans-siliceous or siliceous and aluminous materials [50-52]. It is typically viewed as non-plastic fine silt (ML) when using the Unified Soil Classification System (USCS). Class F fly ash is not used as often because it requires an activator, either lime or cement, to form pozzolanic stabilized mixtures (PSMs) since it is not a self-cementing material [53, 54]. Zulkifley et al. [55] assessed the effect of offspecification fly ash on the engineering properties of tropical soils from Hawaii. They observed that the fly ash reduced the liquid limit and plasticity index, and enhanced the California bearing ratio (CBR) and unconfined compressive strength. Radhakrishnan et al. [56] performed unconfined compressive strength (UCS) and one-dimensional free swell tests on soil-lime mixtures altered with Class F fly ash. Observations showed that lime and fly ash are a good combination for stabilizing silty and sandy soils. It drastically increased the stiffness of the final product. Rupnow et al. [57] used Class C fly ash with lime to develop guidelines for estimating the coefficient of structural layer for the base layer of flexible pavement. The required base layer thickness decreased with the addition of both additives. Fly ash, when mixed with lime, can be used effectively to stabilize most coarse- and medium-grained soils; however, the PI should not be greater than 25 . Soils classified by the USCS as SW, SP, SP-SC, SW-SC, SW-SM, GW, GP, GP-GC, GW-GC, GP-GM, GW-GM, GC-GM, and SC-SM can be stabilized with fly ash.

\section{Soil stabilization using fibers}

The use of hair-sized polypropylene fibers in soil stabilization requests has been common in soil stabilization projects for its low cost compared with other stabilization agents. These materials have a high resistance towards chemical and biological degradation and do not cause leaching in the soil [58]. Sharma et al. [59] studied the improvement in the properties of swelling clay using hay fibers. They found that there was no considerable or reasonable change in the Atterberg limits due to introduction of hay fiber. The maximum dry density (MDD) decreased with the addition of hay. The optimum moisture content $(\mathrm{OMC})$ decreased with increasing hay content up-to $1.0 \%$ then began to decrease. The shrinkage limit decreased with increasing hay content up-to $1.0 \%$ 
then increased. The unconfined compression strength decreased with increasing of hay content to soil ratio. The direct shear strength increased notably with hay addition. The tensile strength of the air dried mixture increased with hay addition and the swelling decreased with hay addition.

Mirzababaei et al. [60] studied unconfined compressive strength (UCS) of reinforced clays with the waste of carpet fibers. They found that carpet waste fibers mixed with clay soils, prepared at the same dry unit weight, can considerably increase the unconfined compression strength (UCS), decrease the post peak strength loss, and alter the failure behavior from brittle to ductile. The results also indicated that the relative benefit of fibers to enhance the UCS of the clay soils is largely dependent on initial dry unit weight and water content of the soil. Cristelo et al. [61] studied the performance of fiber reinforced clayey soil. They found that the excessively compressible clayey soil reinforced with randomly mixed fibers, resulted in higher ultimate bearing capacity, and lesser settlement at the ultimate load. Yilmaz [62] in studying the compaction characteristics of reinforced soil, found that the addition of fiber, affected compaction behavior of samples. The increment in fiber content and length of fiber caused increment in optimum moisture content $(\mathrm{OMC})$ and slight decrement of maximum dry density (MDD). Anagnostopoulos et al. [63] found that with the inclusion of fibers into the soil, the unconfined compressive strength and the corresponding strain at failure increase up to an optimum fiber content and length, and decrease thereafter. In addition; inclusion of fibers in soil increases the strain at failure, and therefore makes the reinforced soil matrix more ductile. The settlement under a particular load in unreinforced soil is much more than the reinforced soil. Minimum settlement being observed for the soil reinforced with polypropylene fibers.

Anggraini et al. [21] studied the stiffness and strength response of coir fiber-reinforced tropical soil. They found that the stress-strain behavior of soil improved by incorporating coir fibers into the soil. The maximum increase in strength was observed when the fiber length is between 15 and $25 \mathrm{~mm}$. The stiffness of soil increases and also the immediate settlement of soil reduced considerably due to the inclusion of fibers in the soil. Shukla et al. [64] studied analytical model of granular soils reinforced with fibers, under high confining pressures. They found that the apparent cohesion and shear strength increase is proportional to the fiber content and aspect ratio. The increase in shear strength of the granular soil stabilized with fibers was mostly from the apparent cohesion, and the contribution from the increase in normal confining stress was quite limited. Estabragh et al. [20] studied the mechanical behavior of a fiber-clay composite with natural fiber. They found that the inclusion of the fiber reinforcement within the soil causes a decrease in pre-consolidation stress and increases compressibility and swelling indices. In addition, the strength and angle of internal friction increase considerably for the total and effective stresses.

\section{Mechanisms of stabilization}

Mechanisms of stabilization that utilize cement, lime, or fly ash were summarized by Little [40] as follows: 
- Cation exchange: sodium, magnesium, and other cations are replaced by the calcium cations from the available calcium hydroxide.

- Flocculation and agglomeration: flocculation of the clay particles increases the effective grain size and reduces plasticity, thus increasing the strength of the matrix.

- Pozzolanic reaction: the high $\mathrm{pH}$ environment created by the available calcium hydroxide solubilizes silicates and aluminates at the clay surface, which in turn react with calcium ions to form cementitious products that are composed primarily of calcium silicate hydrates or calcium aluminate hydrates, or both.

- Carbonate cementation: calcium oxide reacts with carbon dioxide from the atmosphere to form calcium carbonate precipitates, which cement the soil particles.

Cementitious hydration reaction, where calcium silicates and/or calcium aluminates, which are chemically combined in the production of Portland cement clinker or in the coal burning (fly ash) process, hydrate rapidly (within a few hours) for calcium silicate and/or calcium aluminate hydrates. The chemical reactions during the hydration procedure include, but are not limited to, some or all of the reactions listed below [65].

$$
\begin{aligned}
& 2 \mathrm{C}_{2} \mathrm{~S}+6 \mathrm{H}_{2} \mathrm{O} \rightarrow \mathrm{C}_{3} \mathrm{~S}_{2} \mathrm{H}_{3}+3 \mathrm{Ca}(\mathrm{OH})_{2} \\
& 2 \mathrm{C}_{2} \mathrm{~S}+4 \mathrm{H}_{2} \mathrm{O} \rightarrow \mathrm{C}_{3} \mathrm{~S}_{2} \mathrm{H}_{3}+\mathrm{Ca}(\mathrm{OH})_{2} \\
& \mathrm{C}_{3} \mathrm{~A}+3\left(\mathrm{CaSO}_{4} 2 \mathrm{H}_{2} \mathrm{O}\right) \rightarrow 26 \mathrm{H}_{2} \mathrm{O} \rightarrow \mathrm{C}_{3} \mathrm{~A} \cdot 3 \mathrm{CaSO}_{4} \cdot 32 \mathrm{H}_{2} \mathrm{O} \\
& 2 \mathrm{C}_{3} \mathrm{~A}+\mathrm{C}_{3} \mathrm{~A}_{3} \mathrm{CaSO}_{4} 32 \mathrm{H}_{2} \mathrm{O} \rightarrow 3\left[\mathrm{C}_{3} \mathrm{ACaSO}_{4} 12 \mathrm{H}_{2} \mathrm{O}\right] \\
& \mathrm{C}_{3} \mathrm{~S}+\mathrm{Ca}(\mathrm{OH})_{2}+12 \mathrm{H}_{2} \mathrm{O} \rightarrow \mathrm{C}_{3} \mathrm{~A} \mathrm{Ca}(\mathrm{OH})_{2} 12 \mathrm{H}_{2} \mathrm{O} \\
& \mathrm{C}_{4} \mathrm{AF}+3\left(\mathrm{CaSO}{ }_{4} 2 \mathrm{H}_{2} \mathrm{O}\right)+27 \mathrm{H}_{2} \mathrm{O} \rightarrow \mathrm{C}_{3}(\mathrm{AF}) 3 \mathrm{CaSO}_{4} 32 \mathrm{H}_{2} \mathrm{O}+\mathrm{Ca}(\mathrm{OH})_{2} \\
& 2 \mathrm{C}_{4} \mathrm{AF}+\mathrm{C}_{3}(\mathrm{AF}) 3 \mathrm{CaSO} \mathrm{C}_{4} 32 \mathrm{H}_{2} \mathrm{O}+6 \mathrm{H}_{2} \mathrm{O} \rightarrow 3\left[\mathrm{C}_{3}(\mathrm{AF}) \mathrm{CaSO}_{4} 12 \mathrm{H}_{2} \mathrm{O}\right]+ \\
& 2 \mathrm{Ca}(\mathrm{OH})_{2} \\
& \mathrm{C}_{4} \mathrm{AF}+10 \mathrm{H}_{2} \mathrm{O}+2 \mathrm{Ca}(\mathrm{OH})_{2} \rightarrow \mathrm{C}_{3} \mathrm{AH}_{6}-\mathrm{C}_{3} \mathrm{FH}_{6} \text { (Solid Solution) }
\end{aligned}
$$

Two popular theories on the mechanisms of stabilization, namely the crystalline theory by Le Chatelier [66], and the gel theory proposed by Taylor [67], have been integrated into a combined gel/crystalline theory that describe the different stages of curing. $\mathrm{Li}$ [68] provided a detailed description of the hydration process of cement concrete: If a proper amount of moisture is available to ensure complete hydration of the cement, then each cement particle is covered with water and thus forms a gel-like film. These coated particles of cement coat the aggregate or soil particles as well. At this stage, the cement has not begun to set. The reaction between the water and the cement forms small single crystals. With the development of hydration, the single crystals begin to grow into one another and form a crystalline network. The adjoining crystals are attracted to one another by van der Waals forces instead of a chemical bond. Figure 1 illustrates this process. 


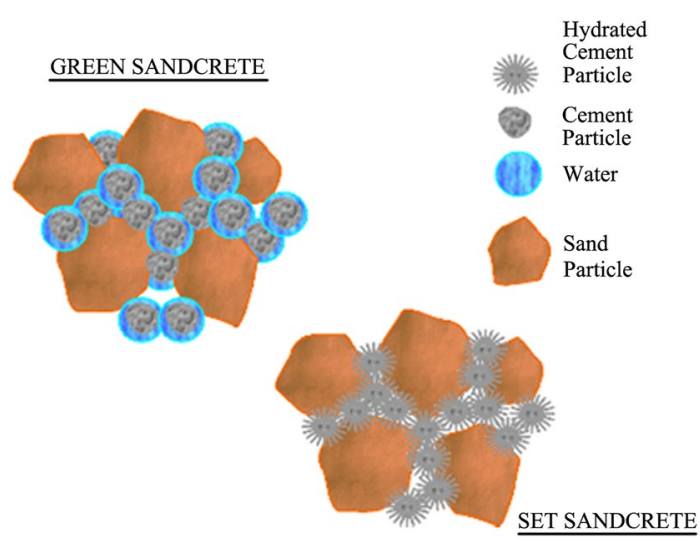

Fig. 1 Bonding process between cement particles and sand particles [68]

\section{Advantages and disadvantages of calcium-based additives}

Soil stabilization using calcium-based additives involve advantages and disadvantages. Some of the advantages and disadvantages of calcium-based additives are discussed here.

\section{Advantages}

The following list presents some of the engineering advantages of calcium-based soil stabilization [69]:

- Functions as a working platform (expedites construction).

- Reduces the need for dusting.

- Waterproofs the soil.

- Upgrades marginal aggregates or soils.

- Improves strength.

- Improves durability.

- Controls volume changes of soils.

- Improves soil workability.

- Dries wet soils.

- Reduces pavement thickness requirements.

- Conserves aggregate.

- Reduces construction and haul costs.

- Conserves energy.

- Provides a temporary or permanent wearing surface.

In spite of the significant advantages mentioned above, many serious disadvantages are inherent from calcium-based stabilizers. These disadvantages are as follows:

\section{Negative environmental impact}

Global warming is a serious threat which our planet is facing [70]. Carbon dioxide $\left(\mathrm{CO}_{2}\right)$ is one of the main factors for this warming [71-74]. Cement manufacturing is a process which emits $\mathrm{CO}_{2}$ in large amount $[71,75-77]$. Cement industry alone produces about 
$10 \%$ of total $\mathrm{CO}_{2}$ emission [78]. Cement manufacturing emits $\mathrm{CO}_{2}$ through decarbonisation of limestone, burning fossil fuels, electricity, and transportation.

\section{Sulfate attack and carbonation}

Two deleterious chemical reactions occur in the soils treated with calcium-based materials. One of the sulfate salts existing in the soil and two lime carbonation. In the soils containing sulfates, any calcium-based additives results in heaving and disintegration leading to a loss in strength [79-81]. Soil composition, groundwater and mixed water can be the source of sulfates [82-84]. Chemical reaction between calcium and aluminum present in the soil mineralogy in the company of soluble sulfate and water produce ettringite and/or thaumasite. Ettringite is a hydrous calcium aluminium sulfate mineral with formula: $\mathrm{Ca}_{6} \mathrm{Al}_{2}\left(\mathrm{SO}_{4}\right) 3(\mathrm{OH})_{12} \cdot 26 \mathrm{H}_{2} \mathrm{O}$. It is a colorless to yellow mineral crystallizing in the trigonal system. The prismatic crystals are typically colorless, turning white on partial dehydration. Calcium sulfate sources, such as gypsum, are intentionally added to Portland cement to regulate early hydration reactions to prevent flash setting, improve strength development, and reduce drying shrinkage. Sulfate and aluminate are also present in supplementary cementitious materials and admixtures. Gypsum and other sulfate compounds react with calcium aluminate in the cement to form ettringite within the first few hours after mixing with water. Most of the sulfate in the cement is normally consumed to form ettringite at early ages. The formation of ettringite in the fresh, plastic concrete is the mechanism that controls stiffening. At this stage ettringite is uniformly and discretely dispersed throughout the cement paste at a submicroscopic level (less than a micrometer in cross-section). Thaumasite is a silicate mineral with chemical formula $\mathrm{Ca}_{3} \mathrm{Si}(\mathrm{OH}) 6\left(\mathrm{CO}_{3}\right) \cdot\left(\mathrm{SO}_{4}\right) \cdot 12 \mathrm{H}_{2} \mathrm{O}$. It occurs as colorless to white prismatic hexagonal crystals, typically as acicular radiating groups. It also occurs as fibrous masses. Its Mohs hardness is 3.5 and it has a specific gravity of $1.88-1.90[85,86]$.

\section{Effect of organic materials}

Chan and Heenan [87] suggested that the high microbial biomass present in the organic soil activates rates of decomposition in organic soils treated with lime resulting into reduction in $\mathrm{pH}$ value. In addition, clay minerals are in lesser quantity in the organic soil. Therefore, the organic materials slow down the pozzolanic reaction necessary to attain soil strength $[88,89]$. The organic soil is characterized by high water with holding capacity that may lead to a reduction in available water for the hydration process. Furthermore, organic materials coat the additive particles thus holding up the hydration process [90].

According to Morse et al. [91], there is a great tendency for the reaction between calcium ions and black humic acid generated from lime to produce insoluble calcium humic acid. Hossain et al. [92] indicated that the decomposition of organic materials hinders the polymerization of silicate. Thus, the cementitious formation is blocked by organic materials. Though, it is key to know that not all of the organic materials block cementitious reaction. Some have no effects such as chloronaphthalene and others retard hydration reaction but do not affect soil strength gain such as ethylene glycol, benzoic acid, cellulose [93, 94]. 
Cement-treated soil to face the similar situation as mentioned for soils treated with lime. Sasanian and Newson [95] and Zhang et al. [96] observed that the soil treated with cement is susceptible to organic materials hindering the chemical reaction which produces cementitious materials. Huat et al. [93] reported that soil containing organic acids and having $\mathrm{pH}$ less than 9 inhibit the cementing reaction. For the purpose to reduce the negative effect of organic materials, bentonite is added to the organic soil. This treatment provides two benefits, one, bentonite has high water retention ability, which is favorable for lime hydration. Two, bentonite is the source of silica for pozzolanic reaction and can become a filler [97, 98]. Kaolinite and zeolite may also be used for lime treated soil having humic acid [98-100]. This gives enough amount of silica that is required for pozzolanic process.

\section{Problems in sulfate soils stabilized with lime/cement}

Though lime stabilization improves the volume and strength characteristics of the expansive soils, there are some limitations to lime stabilization. These limitations include the presence of organic carbon and soluble sulfates. It has been reported that the presence of organic carbon in excess of one percent can interfere with the pozzolanic reactions, leading to low strength gains. Compared to organic carbon, the presence of sulfates is of higher concern because lime treatment in these types of soils leads to excessive heaving and pavement failures $[7,8,81,101-105]$. It has been reported that when soils contain sulfate minerals such as gypsum $\left(\mathrm{CaSO}_{4} \cdot 2 \mathrm{H}_{2} \mathrm{O}\right)$ and sodium sulfate $\left(\mathrm{Na}_{2} \mathrm{SO}_{4}\right)$ in their natural formation and are treated with calcium-based stabilizers, adverse reactions occur, causing severe heave and pavement distress. These adverse reactions are due to formation of expansive minerals, ettringite $\left(\mathrm{Ca}_{6} \cdot\left[\mathrm{Al}(\mathrm{OH})_{6}\right]_{2} \cdot\left(\mathrm{SO}_{4}\right)_{3} \cdot 26 \mathrm{H}_{2} \mathrm{O}\right)$, and thaumasite $\left(\mathrm{Ca}_{6} \cdot\left[\mathrm{Si}(\mathrm{OH})_{6}\right]_{2} \cdot\left(\mathrm{SiO}_{4}\right) \cdot\left(\mathrm{CO}_{3}\right)_{2} \cdot 24 \mathrm{H}_{2} \mathrm{O}\right)$. This phenomenon was first reported by Sherwood [3]. There are several sources of sulfates in soils, produced from primary or secondary origin. Primary sources can be defined as the direct sources of sulfates in their natural form, as sulfate-bearing minerals such as gypsum while, the secondary sources are those that are not a direct source of sulfate but give out sulfates as a by-product of oxidation or other forms of chemical interactions. The following section highlights these sources.

Recent studies have revealed that the soil containing sulfates, when treated with lime or cement undergo excessive swelling and pavement failures $[8,106$, 107]. These failures are due to the formation of ettringite $[3,86,108]$. Reactions between lime, alumina, and sulfates in the soils produce an expansive crystalline mineral called ettringite $\left(\mathrm{Ca}_{6} \cdot\left[\mathrm{Al}(\mathrm{OH})_{6}\right]_{2} \cdot\left(\mathrm{SO}_{4}\right)_{3} \cdot 26 \mathrm{H}_{2} \mathrm{O}\right)$, and thaumasite $\left(\mathrm{Ca}_{6} \cdot\left[\mathrm{Si}(\mathrm{OH})_{6}\right]_{2} \cdot\left(\mathrm{SiO}_{4}\right) \cdot\left(\mathrm{CO}_{3}\right)_{2} \cdot 24 \mathrm{H}_{2} \mathrm{O}\right)$. Generally, it is recommended that for the sulfate enriched soils, lime and cement treatments should be chosen cautiously $[86,109$, $110]$.

\section{Soil-lime-sulphate reactions}

Lime-soil reactions are grouped into two, short term and long term reactions. Short term reactions are flocculation, $\mathrm{pH}$ and cation exchange reactions, lime migration carbonation, and these affect the physical properties of the soil such as consistency limits and grain size distribution. The long-term pozzolanic reactions consist of formation 
of various products, resulting in the growth new materials and affect the strength and compressibility of clays [104, 111]. Takemoto and Uchikawa [112] explained the reaction mechanism of $\mathrm{C}_{3} \mathrm{~S}$ pozzolanic compounds, and ettringite formation through pozzolanic reactions, in a schematic way as shown in Fig. 3.

Takemoto and Uchikawa [112] proposed schematic explanations of the $\mathrm{C}_{3} \mathrm{~S}$-pozzolan reaction and $\mathrm{C}_{3} \mathrm{~A}$-pozzolan reaction, which are shown in Figs. 2 and 3, respectively. According to the authors, in $\mathrm{C}_{3} \mathrm{~S}$-pozzolan system, calcium ions dissolved from $\mathrm{C}_{3} \mathrm{~S}$ route around freely in liquid and are adsorbed on the surfaces of pozzolan particles. $\mathrm{C}-\mathrm{S}-\mathrm{H}$ made by the hydration of $\mathrm{C}_{3} \mathrm{~S}$ precipitate as the hydrates of high $\mathrm{Ca} / \mathrm{Si}$ ratio on the surface of $\mathrm{C}_{3} \mathrm{~S}$ grains and as the porous hydrates of low $\mathrm{Ca} / \mathrm{Si}$ ratio on the surfaces of pozzolan particles. Attack of the pozzolan surface in water brings about gradual dissolution of $\mathrm{Na}^{+}$and $\mathrm{K}^{+}$, resulting in $\mathrm{Si}$ and $\mathrm{Al}$ rich amorphous layer on the surfaces. Dissolved $\mathrm{Na}^{+}$and $\mathrm{K}^{+}$raise the $\mathrm{OH}^{-}$concentration and speed up the dissolution of $\mathrm{SiO}_{4}^{-4}$ and layer. Due to the osmotic pressure, the layer swells slowly and the void between layer and pozzolan particle is formed. When the pressure in the void breaks the film, $\mathrm{SiO}_{4}^{-4}$ and $\mathrm{AlO}_{2}{ }^{-}$diffuse into the $\mathrm{Ca}^{2+}$ rich solution. In addition, $\mathrm{C}-\mathrm{S}-\mathrm{H}$ and $\mathrm{Ca}-\mathrm{Al}$ hydrate precipitate on the surface of outer hydrates of $\mathrm{C}_{3} \mathrm{~S}$ particles and to a slight degree on

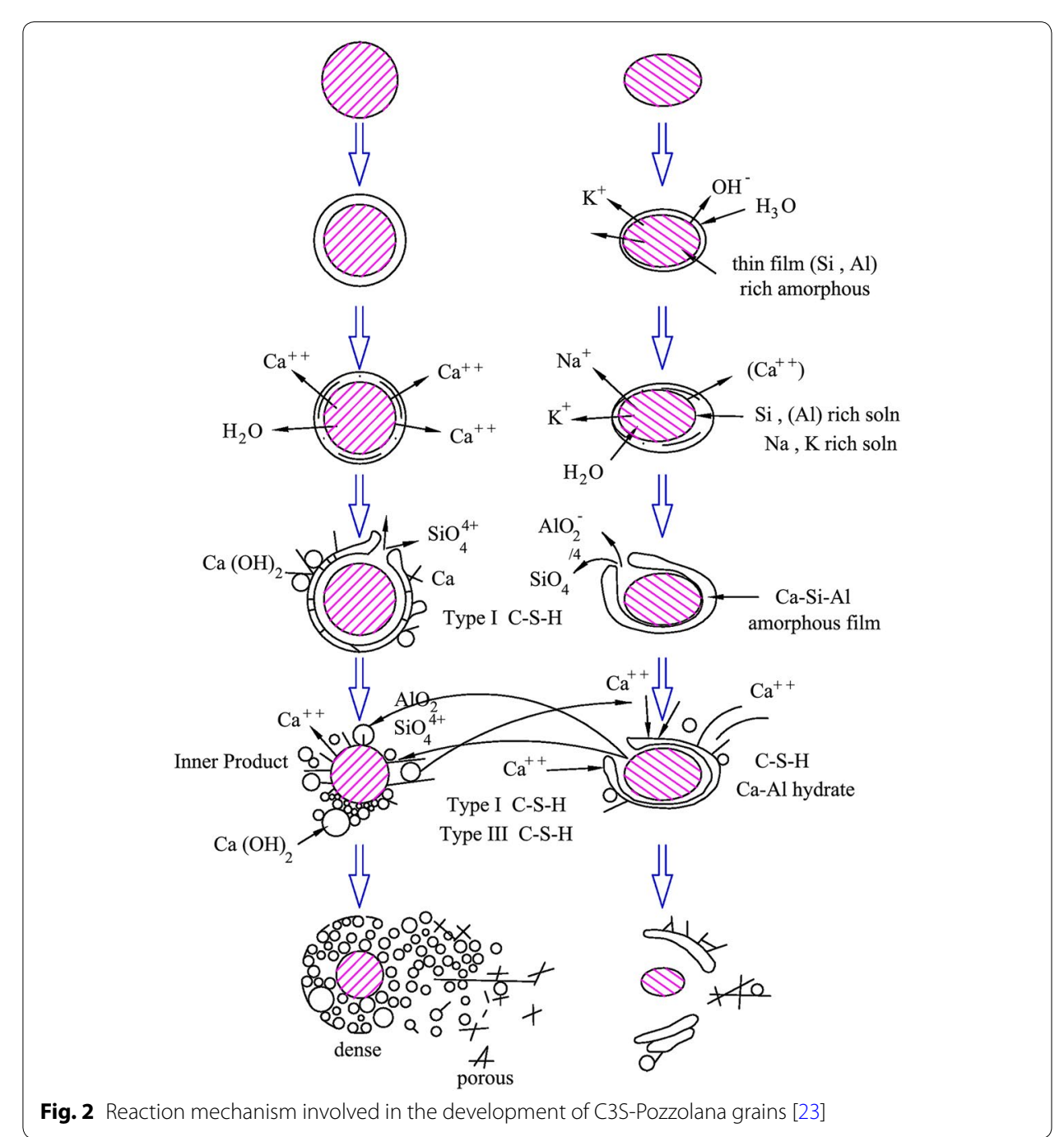




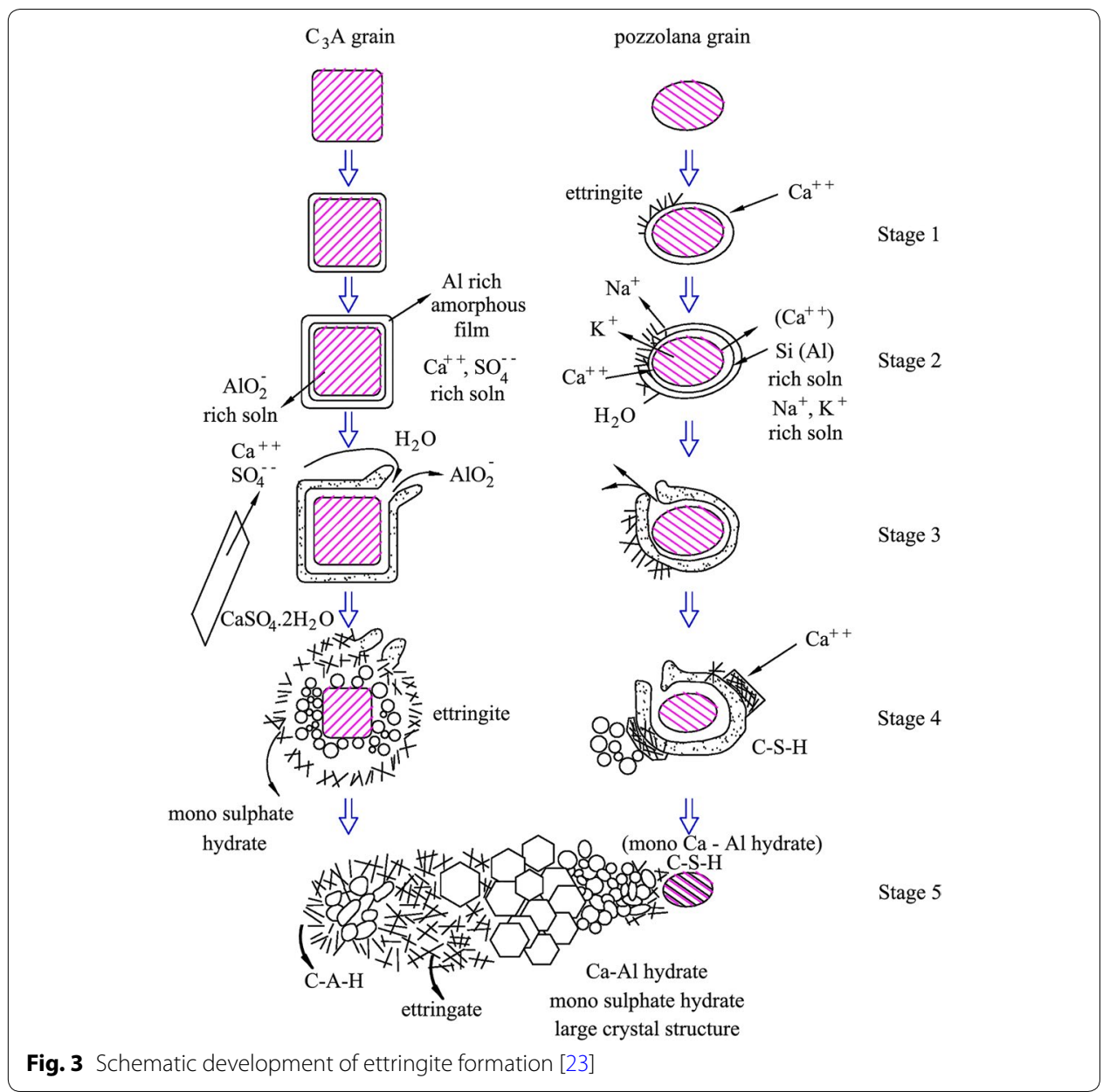

the broken film. Vacant space remains inside the film as the hydrates do not precipitate there because of high concentration of alkalies. For pozzolans with low alkalies, damage of amorphous $\mathrm{Si}, \mathrm{Al}$ rich film enables $\mathrm{Ca}^{2+}$ to travel into the inside of the film and precipitate calcium silicate and calcium aluminate hydrates on the surface of pozzolan grain. Therefore, no space is witnessed between pozzolan grains and hydrates.

The hydration of the $\mathrm{C}_{3} \mathrm{~A}$-pozzolan system was first observed by Uchikawa and Uchida [23]. Figure 3 illustrates the schematic development of the $\mathrm{C}_{3} \mathrm{~A}$-pozzoloan system in the presence of calcium hydroxide and gypsum. Uchikawa and Uchida [112], pointed out that the presence of the pozzolan speeds up the hydration of $\mathrm{C}_{3} \mathrm{~A}$ by adsorbing $\mathrm{Ca}^{2+}$ from the liquid phase and by providing precipitation sites for ettringite and other hydrates. The $\mathrm{C}_{3} \mathrm{~A}$-pozzolan reaction system is comparable to Aluminate hydrate, and calcium silicate hydrate are shaped on the surface film outside the pozzolan particles of on the surface hydrate layer of the $\mathrm{C}_{3} \mathrm{~A}$ particles, depending on the concentration of $\mathrm{Ca}^{2+}$ and $\mathrm{SiO}_{4}^{-2}$ in solution. 


\section{Conclusion}

Based on the short review of this study, desiccation, swelling, shrinkage, and cracks in clayey soil are common natural phenomena, and it significantly impacts the soil's mechanical and hydraulic behavior. Treatment of the soil with cement reduces the volume changes in soils but this type of treatment becomes unsuitable for soils with high plasticity index. Soil treated with lime and exposed to wetting and drying cycles results in loss of cohesion between the grains of soil and lime, which leads to increase in soil volume. Thus, the method of treatment with lime is only good for places that are not exposed to the wetting and drying cycles. Fiber treatment is considered one of the best methods in the prevention of cracks because, with increase in the content, there is a great reduction in the cracks. Fiber also increases the strength of the soil but it is not effective for all type of soils especially clayey soils where hydraulic conductivity have been found to increase with the addition of fiber.

\section{Authors' contributions}

$\mathrm{AAF}, \mathrm{CGO}, \mathrm{AAF}$, and MSB contributed to the design and implementation of the research, to the analysis of the results. Also, AAF wrote the manuscript. All authors read and approved the final manuscript.

\section{Author details}

${ }^{1}$ Department of Civil \& Structural Engineering, Universiti Kebangsaan Malaysia (UKM), Bangi, Selangor, Malaysia. ${ }^{2}$ Charles E. Via Department of Civil and Environmental Engineering, Virginia Tech, Blacksburg, VA 24061, USA.

\section{Acknowledgements}

The authors gratefully acknowledge the support from Department of Civil Engineering, Universiti Kebangsaan Malaysia, which provided facility for this research.

\section{Competing interests}

The authors declare that they have no competing interests.

\section{Ethics approval and consent to participate}

The presented work is part of research project entitled "Soil improvement using nanomaterials". There is no any ethical conflict. Authors on behalf of an associated organization fully authorize to publish research.

\section{Publisher's Note}

Springer Nature remains neutral with regard to jurisdictional claims in published maps and institutional affiliations.

Received: 11 September 2016 Accepted: 30 November 2017

Published online: 16 December 2017

\footnotetext{
References

1. Das BM (2015) Principles of foundation engineering. Cengage learning, Boston

2. Hausmann MR (1990) Engineering principles of ground modification. McGraw-Hill, Maidenheach

3. Sherwood P (1993) Soil stabilization with cement and lime. Transport Research Laboratory, College Park

4. Naeini SA, Naderinia B, Izadi E (2012) Unconfined compressive strength of clayey soils stabilized with waterborne polymer. KSCE J Civ Eng 16(6):943-949

5. Prusinski J, Bhattacharja S (1999) Effectiveness of Portland cement and lime in stabilizing clay soils. Transp Res Rec J Transp Res Board 1652:215-227

6. McDowell C (1959) Stabilization of soils with lime, lime-flyash, and other lime reactive materials. Highway Res Board Bull 231:60-66

7. Puppala AJ, Hanchanloet S, Jadeja M, Burkart B (1999) Sulfate induced heave distress: a case study. In: Proceedings, transportation research board annual meeting, Washington DC, USA

8. Saussaye L, Boutouil M, Baraud F, Leleyter L (2015) Influence of sulfate and chloride ions on the geotechnical and microstructural properties of soils treated with hydraulic binders: individual and coupling effects. Eng Geol 189:98-103

9. Kaminskas R, Barauskas I (2014) Influence of pozzolana on sulfate attack of cement stone affected by chloride ions. Mater Struct 47(11):1901-1910

10. Firoozi AA, Taha MR, Firoozi AA (2014) Nanotechnology in civil engineering. Electron J Geotech Eng 19:4673-4682

11. Firoozi AA, Taha MR, Firoozi AA, Khan TA (2014) Assessment of nano-zeolite on soil properties. Aust J Basic Appl Sci 8(19):292-295

12. Wang L (2002) Cementitious stabilization of soils in the presence of sulfate. Doctoral dissertation
} 
13. Little DN, Nair S (2009) Recommended practice for stabilization of subgrade soils and base materials. National cooperative highway research program. Transportation research board of the national academies

14. Abu-Farsakh M, Dhakal S, Chen Q (2015) Laboratory characterization of cementitiously treated/stabilized very weak subgrade soil under cyclic loading. Soils Found 55(3):504-516

15. Khan TA, Taha MR, Firoozi AA, Firoozi AA (2015) Strength tests of enzyme-treated illite and black soil mixtures. In: Proceedings of the institution of civil engineers-engineering sustainability, vol. 169, no. 5. Thomas Telford Ltd, Westminster. pp 214-222

16. Firoozi AA, Firoozi AA, Baghini MS (2017) A review of physical and chemical clayey. J Civ Eng Urban 6(4):64-71

17. Chittoori BCS (2008) Clay mineralogy effects on long-term performance of chemically treated expansive clays, Doctoral dissertation, The University of Texas at Arlington

18. Chittoori BC, Puppala AJ, Wejrungsikul T, Hoyos LR (2013) Experimental studies on stabilized clays at various leaching cycles. J Geotech Geoenviron Eng 139(10):1665-1675

19. Croft JB (1967) The influence of soil mineralogical composition on cement stabilization. Geotechnique 17(2):119-135

20. Estabragh AR, Bordbar AT, Javadi AA (2013) A study on the mechanical behavior of a fiber-clay composite with natural fiber. Geotech Geol Eng 31(2):501-510

21. Anggraini V, Huat BBK, Asadi A, Nahazanan H (2014) Effect of coir fibre and lime on geotechnical properties of marine clay soil. In: 7th International congress on environmental geotechnics: iceg2014, engineers, Australia. p 1430

22. Parsons R, Milburn J (2003) Engineering behavior of stabilized soils. Transp Res Rec J Transp Res Board 1837:20-29

23. Uchikawa, H., and Uchida, S. (1980, July). Influence of pozzolana on the hydration of $C_{3}$ A. In Proceedings of the 7th International Congress on the Chemistry of Cement, Sub-Theme IV, Paris, France, pp 24-29

24. Kezdi A (1979) Stabilized earth roads development in geotechnical engineering. Elsevier, London

25. Deng SP, Tabatabai MA (1997) Effect of tillage and residue management on enzyme activities in soils: III. Phosphatases and arylsulfatase. Biol Fertil Soils 24(2):141-146

26. Jones LD, Jefferson I (2012) Expansive soils. ICE Publishing, London, pp 413-441

27. Al-Rawas AA, Hago AW, Al-Sarmi H (2005) Effect of lime, cement and Sarooj (artificial pozzolan) on the swelling potential of an expansive soil from Oman. Build Environ 40(5):681-687

28. Firoozi AA, Taha MR, Firoozi AA (2014) Analysis of the load bearing capacity of two and three-layered soil. Electron J Geotech Eng 19:4683-4692

29. Makusa GP (2012) Soil stabilization methods and materials in engineering practice. Luleå University of Technology, Luleå

30. Sirivitmaitrie C, Puppala A, Saride S, Hoyos L (2011) Combined lime-cement stabilization for longer life of lowvolume roads. Transp Res Rec J Transp Res Board 2204:140-147

31. Ronoh V, Too JK, Kaluli JW, Victor MR (2014) Cement effects on the physical properties of expansive clay soil and the compressive strength of compressed interlocking clay blocks. Eur Int J Sci Technol 3(8):74-82

32. Khemissa M, Mahamedi A (2014) Cement and lime mixture stabilization of an expansive over consolidated clay. Appl Clay Sci 95:104-110

33. Pedarla A, Chittoori S, Puppala A (2011) Influence of mineralogy and plasticity index on the stabilization effectiveness of expansive clays. Transp Res Rec J Transp Res Board 2212:91-99

34. Ismail A, Baghini MS, Karim MR, Shokri F, Al-Mansob RA, Firoozi AA, Firoozi AA (2014) Laboratory investigation on the strength characteristics of cement-treated base. In: Applied mechanics and materials, vol 507. Trans Tech Publications, Zürich. pp 353-360

35. Bell FG (1996) Lime stabilization of clay minerals and soils. Eng Geol 42(4):223-237

36. Tedesco DV (2006) Hydro-mechanical behaviour of lime-stabilised soils, Doctoral dissertation, Ph.D. thesis, UniversitÃ degli Studi di Cassino FacoltÃ di Ingegneria

37. Louafi B, Hadef B, Bahar R (2015) Improvement of geotechnical characteristics of clay soils using lime. In: Advanced materials research, vol 1105. Trans Tech Publications, Zürich. pp 315-319

38. Pei X, Zhang F, Wu W, Liang S (2015) Physicochemical and index properties of loess stabilized with lime and fly ash piles. Appl Clay Sci 114:77-84

39. Jung C, Bobet A (2008) Post-construction evaluation of lime-treated soils. https://doi.org/10.5703/1288284313443

40. Little DN (1999) Evaluation of structural properties of lime stabilized soils and aggregates. Prepared for the national lime association, vol 1, pp 1-89

41. Solanki P, Zaman M, Dean J (2010) Resilient modulus of clay subgrades stabilized with lime, class C fly ash, and cement kiln dust for pavement design. Transp Res Rec J Transp Res Board 2186:101-110

42. Al-Kiki IM, Al-Atalla MA, Al-Zubaydi AH (2011) Long term strength and durability of clayey soil stabilized with lime. Eng Tech J 29(4):725-735

43. Arman A, Barclay RT, Casias TJ, Crocker DA, Adaska WS, De Graffenreid RL, Super DW (1990) State-of-the-art report on soil cement. ACl Mater J 87(4):395-417

44. Broderick GP, Daniel DE (1990) Stabilizing compacted clay against chemical attack. J Geotech Eng 116(10):1549-1567

45. Haraguchi M, Miyadera K, Uemura K, Sumizawa T, Furukawa T, Yamada K, Yamada Y (1994) Angiogenic activity of enzymes. Nature 368:198

46. Kassim KA, Chern KK (2004) Lime stabilized Malaysian cohesive soils. Malays J Civil Eng 16(1):13-23

47. Abdullah N, Abdullah R (2013) Effect of humic acid on microstructure of lime-treated organic clay. Int J Eng 2(11):1827-1833

48. Ghobadi MH, Abdilor Y, Babazadeh R (2014) Stabilization of clay soils using lime and effect of pH variations on shear strength parameters. Bull Eng Geol Env 73(2):611-619

49. Saeeda KAH, Kassima KA, Yunusa NZM, Nurb H (2015) Physico-chemical characterization of lime stabilized tropical kaolin clay. J Teknol 72(3):83-90 
50. Bose B (2012) Geo engineering properties of expansive soil stabilized with fly ash. Electron J Geotech Eng 17:1339-1353

51. Tastan EO, Edil TB, Benson CH, Aydilek AH (2011) Stabilization of organic soils with fly ash. J Geotech Geoenviron Eng 137(9):819-833

52. Pandian NS (2013) Fly ash characterization with reference to geotechnical applications. J Indian Inst Sci 84(6):189-216

53. Phani Kumar BR, Sharma RS (2004) Effect of fly ash on engineering properties of expansive soils. J Geotech Geoenviron Eng 130(7):764-767

54. Firoozi AA, Taha MR, Firoozi AA, Khan TA (2015) The influence of freeze-thaw cycles on unconfined compressive strength of clay soils treated with lime. J Teknol 76(1):107-113

55. Zulkifley MTM, Ng TF, Raj JK, Hashim R, Bakar AFA, Paramanthan S, Ashraf MA (2014) A review of the stabilization of tropical lowland peats. Bull Eng Geol Env 73(3):733-746

56. Radhakrishnan G, Kumar MA, Raju GVRP (2014) Swelling properties of expansive soils treated with chemicals and fly ash. Am J Eng Res 3(4):245-250

57. Rupnow TD, Franklin B, White DJ (2015) Class C fly ash stabilization of recycled asphalt pavement and soil—a case study. In: 2015 world of coal ash (WOCA) conference in Nasvhille, TN, pp 1-19

58. Puppala A, Musenda C (2000) Effects of fiber reinforcement on strength and volume change in expansive soils. Transp Res Rec J Transp Res Board 1736:134-140

59. Sharma V, Vinayak HK, Marwaha BM (2015) Enhancing compressive strength of soil using natural fibers. Constr Build Mater 93:943-949

60. Firoozi AA, Taha MR, Firoozi AA, Khan TA (2015) Effect of ultrasonic treatment on clay microfabric evaluation by atomic force microscopy. Measurement 66:244-252

61. Cristelo N, Cunha VM, Dias M, Gomes AT, Miranda T, Araújo N (2015) Influence of discrete fibre reinforcement on the uniaxial compression response and seismic wave velocity of a cement-stabilised sandy-clay. Geotext Geomembr 43(1):1-13

62. Yilmaz Y (2015) Compaction and strength characteristics of fly ash and fiber amended clayey soil. Eng Geol 188:168-177

63. Anagnostopoulos CA, Tzetzis D, Berketis K (2014) Shear strength behaviour of polypropylene fibre reinforced cohesive soils. Geomech Geoeng 9(3):241-251

64. Shukla SK, Sivakugan N, Singh AK (2010) Analytical model for fiber-reinforced granular soils under high confining stresses. J Mater Civ Eng 22(9):935-942

65. Hoover CG, Ulm FJ (2015) Experimental chemo-mechanics of early-age fracture properties of cement paste. Cem Concr Res 75:42-52

66. Le Chatelier H (1919) Crystalloids against colloids in the theory of cements. Trans Faraday Soc 14:8-11

67. Taylor MA (1971) General behavior theory for cement pastes, mortars, and concretes. J Proc 68(10):756-762

68. Li X (2014) Shrinkage cracking of soils and cementitiously-stabilized soils: mechanisms and modeling. Washington State University, Pullman

69. Solanki P, Zaman M (2012) Microstructural and mineralogical characterization of clay stabilized using calciumbased stabilizers. In: Scanning electron microscopy. InTech

70. Aksan Z, Çelikler D (2012) The Turkish adaptation study of global warming questionnaire. Proc Social Behav Sci 31:681-684

71. Taha MR, Khan TA, Jawad IT, Firoozi AA, Firoozi AA (2013) Recent experimental studies in soil stabilization with bioenzymes-a review. Electron J Geotech Eng 18:3881-3894

72. Zhang XF, Zhang SY, Hu ZY, Yu G, Pei CH, Sa RN (2012) Identification of connection units with high GHG emissions for low-carbon product structure design. J Clean Prod 27:118-125

73. Ali MB, Saidur R, Hossain MS (2011) A review on emission analysis in cement industries. Renew Sustain Energy Rev 15(5):2252-2261

74. Du Y, Yi Q, Li C, Liao L (2015) Life cycle oriented low-carbon operation models of machinery manufacturing industry. J Clean Prod 91:145-157

75. Mikulčić $\mathrm{H}$, Vujanović $\mathrm{M}$, Duić $\mathrm{N}$ (2013) Reducing the $\mathrm{CO}_{2}$ emissions in Croatian cement industry. Appl Energy 101:41-48

76. Mikulčić $H$, Vujanović M, Fidaros DK, Priesching P, Minić I, Tatschl R, Stefanović G (2012) The application of CFD modelling to support the reduction of $\mathrm{CO}_{2}$ emissions in cement industry. Energy 45(1):464-473

77. Gao T, Shen L, Shen M, Chen F, Liu L, Gao L (2015) Analysis on differences of carbon dioxide emission from cement production and their major determinants. J Clean Prod 103:160-170

78. Liska M, Al-Tabbaa A (2008) Performance of magnesia cements in pressed masonry units with natural aggregates: production parameters optimization. Constr Build Mater 22(8):1789-1797

79. Mitchell JK, Soga K (2005) Fundamentals of soil behavior, 3rd edn. Wiley, New York. ISBN: 978-0-471-46302-3

80. Nair S, Little D (2011) Mechanisms of distress associated with sulfate-induced heaving in lime-treated soils. Transp Res Rec J Transp Res Board 2212:82-90

81. Puppala AJ, Talluri N, Chittoori BC (2014) Calcium-based stabiliser treatment of sulfate-bearing soils. Proc Inst Civil Eng Ground Improv 167(3):162-172

82. Obika B, Freer-Hewish RJ (1990) Soluble salt damage to thin bituminous surfacings of roads and runways. Aust Road Res 20(4):24-41

83. Kinuthia JM, Wild S, Jones GI (1999) Effects of monovalent and divalent metal sulphates on consistency and compaction of lime-stabilised kaolinite. Appl Clay Sci 14(1):27-45

84. Alsharef J, Taha MR, Firoozi AA, Govindasamy P (2016) Potential of using nanocarbons to stabilize weak soils. Appl Environ Soil Sci 2016:1-9. http://dx.doi.org/10.1155/2016/5060531

85. Reis MB (1981) Formation of expansive calcium sulphoaluminate by the action of the sulphate ion on weathered granites in a calcium hydroxide-saturated medium. Cem Concr Res 11(4):541-547 
86. Ismaiel HAH (2006) Treatment and improvement of the geotechnical properties of different soft fine-grained soils using chemical stabilization. Shaker

87. Chan KY, Heenan DP (1999) Lime-induced loss of soil organic carbon and effect on aggregate stability. Soil Sci Soc Am J 63(6):1841-1844

88. Hampton MB, Edil TB (1998) Strength gain of organic ground with cement-type binders. In: Soil improvement for big digs. ASCE, Reston. pp 135-148

89. Ling FNL, Kassim KA, Karim A, Tarmizi A, Chan TW (2013) Stabilization of artificial organic soil at room temperature using blended lime zeolite. In: Advanced materials research, vol 723. Trans Tech Publications, Zürich. pp 985-992

90. Tremblay H, Duchesne J, Locat J, Leroueil S (2002) Influence of the nature of organic compounds on fine soil stabilization with cement. Can Geotech J 39(3):535-546

91. Morse JW, Arvidson RS, Lüttge A (2007) Calcium carbonate formation and dissolution. Chem Rev 107(2):342-381

92. Hossain MT, Hoq A, Akhter M, Hossain AF (2015) Investigation on different properties of organic soil by adding fly ash. Int J Eng Sci Technol 7(1):1

93. Firoozi AA, Olgun G, Mobasser S (2016) Carbon nanotube and civil engineering. Saudi J Eng Technol 1(1):1-4

94. Chenu C, Rumpel C, Lehmann J (2015) Methods for studying soil organic matter: nature, dynamics, spatial accessibility, and interactions with minerals. In: Soil microbiology, ecology and biochemistry, 4th edn, pp 383-419. https://doi.org/10.1016/B978-0-12-415955-6.00013-X

95. Sasanian S, Newson TA (2014) Basic parameters governing the behaviour of cement-treated clays. Soils Found 54(2):209-224

96. Zhang RJ, Lu YT, Tan TS, Phoon KK, Santoso AM (2014) Long-term effect of curing temperature on the strength behavior of cement-stabilized clay. J Geotech Geoenviron Eng 140(8):401-415

97. Dhakal SK (2012) Stabilization of very weak subgrade soil with cementitious stabilizers

98. Wong LS, Hashim R, Ali F (2013) Improved strength and reduced permeability of stabilized peat: focus on application of kaolin as a pozzolanic additive. Constr Build Mater 40:783-792

99. Ling FN, Kassim KA, Karim A, Tarmizi A (2013) Reaction products of lime zeolite stabilized kaolin humic acid. In: Applied mechanics and materials, vol 372. Trans Tech Publications, Zürich. pp 88-96

100. Pakir FB, Abdul Karim ATB, Ling FN, Kassim KA (2013) Effect of humic acid on geochemistry properties of kaolin. In: Advanced materials research, vol 701. Trans Tech Publications, Zürich. pp 310-313

101. Puppala AJ, Wattanasanticharoen E, Punthutaecha K (2003) Experimental evaluations of stabilisation methods for sulphate-rich expansive soils. Ground Improv 7(1):25-35

102. Puppala AJ, Talluri NS, Chittoori BS, Gaily A (2012) Lessons learned from sulfate induced heaving studies in chemically treated soils. In: Proceedings of the international conference on ground improvement and ground control. Research Publishing, vol 1. pp 85-98

103. Mitchell JK (1986) Practical problems from surprising soil behavior. J Geotech Eng 112(3):259-289

104. Rajasekaran G (2005) Sulphate attack and ettringite formation in the lime and cement stabilized marine clays. Ocean Eng 32(8):1133-1159

105. Turkoz M, Savas H, Acaz A, Tosun H (2014) The effect of magnesium chloride solution on the engineering properties of clay soil with expansive and dispersive characteristics. Appl Clay Sci 101:1-9

106. Yong RN, Ouhadi VR, Mohamed AMO (1996) Physicochemical evaluation of failure of stabilized marl soil. In: Proceedings of the 49th Canadian geotechnical conference frontiers in geotechnology, vol 2. pp 769-776

107. Verástegui-Flores RD, Di Emidio G (2014) Impact of sulfate attack on mechanical properties and hydraulic conductivity of a cement-admixed clay. Appl Clay Sci 101:490-496

108. Xu LL, Wang PM, Wu GM, Zhang GF (2014) Effect of calcium sulfate on the formation of ettringite in calcium aluminate and sulfoaluminate blended systems. In: Key engineering materials, vol 599. Trans Tech Publications, Zürich. pp 23-28

109. Hunter D (1988) Lime-induced heave in sulfate-bearing clay soils. J Geotech Eng 114(2):150-167

110. Soga K, Kumar K, Biscontin G, Kuo M (eds.) (2014) Geomechanics from micro to macro. CRC Press, Boca Raton

111. Eisazadeh A (2015) Thermal characteristics of lime-and phosphoric acid-stabilized montmorillonitic and kaolinitic soils. J Therm Anal Calorim 121(3):1239-1246

112. Takemoto K (1980) Hydration of pozzolanic cement. In: 7th International congress chemistry of cement I, paper no. 2

\section{Submit your manuscript to a SpringerOpen ${ }^{\circ}$ journal and benefit from:}

- Convenient online submission

- Rigorous peer review

- Open access: articles freely available online

- High visibility within the field

- Retaining the copyright to your article

Submit your next manuscript at $\gg$ springeropen.com 